\title{
Africa: On the Rise, but to Where?
}

\author{
Franklin Obeng-Odoom \\ School of Built Environment, University of Technology, \\ Sydney, Australia
}

\begin{abstract}
Africa's hitherto negative image is now being rapidly replaced by a new persona: 'Africa on the rise'. Developed mainly from Africa's growth experience, this re-imaging of Africa has generated considerable interest even among Africanists concerned that the continent has often been the target of crisis jokes. Even more notably, the rebranding of Africa has gained traction in corridors of power and centres of finance. For this latter group, however, the narrative signals more than a cultural repackaging. It is about confirming that Africa is ripe and ready to host investment and to open up markets in areas where they did not exist or existed but were not capitalist in form. Either way, however, the 'Africa on the rise' narrative achieves a major political and economic goal. Neglecting ethical questions about sustainable jobs, inequality and ecological crisis, while extolling the virtues of capital accumulation, it extends a particular neoliberal ideology which favours people with market power, not the majority with precarious positions or their relationship with nature.
\end{abstract}

Keywords: economic growth, well-being, jobs, inequality, ecology, Africa

\section{INTRODUCTION}

Once proclaimed 'hopeless' by The Economist, Africa is now regarded as a 'hopeful' continent, incidentally by the same magazine. But why not? The GDP figures in Africa are impressive. Between 2002 and 2007, GDP growth in subSaharan Africa doubled to an average of $6.2 \%$ (Fosu, 2010). This record towers above the average European figure of $3 \%$. Libya even grew by more than $100 \%$ in 2012 only. Globally, about half of the top 10 fastest growing economies in 2012 
were in Africa (Fioramonti, 2014). This image of a fast-growing Africa has now been stitched on everything Africa, with the February 2014 edition of Highlife declaring Lagos as the world's fourth largest fashion city. The growth mantra is now frequently discussed in the international media, such as BBC, ${ }^{1}$ and by the world leaders when they mount international platforms. This optimism is not limited to non-Africans: some African scholars (e.g. Twineyo-Kamugisha, 2012), political parties, leaders and institutions are similarly jubilant (Obeng-Odoom, 2013).

Now that the interest in growth has heightened and African economies are regarded as 'lions on the move' (McKinsey Global Institute, 2010), it is timely to consider whether the well-being of Africans have improved with the growth of their countries' economies by $1 \%, 2 \%, 3 \%$ or even $100 \%$. This is a crucially important issue and hence was the theme to be analysed by the Africans invited to the Heinrich Böll Foundation in Berlin, Germany. Berlin was seeking considered responses to the question: is the rapid and impressive growth in Africa to be celebrated for its well-being producing features? I reflect on this question and its ramifications as one of the invitees.

For orthodox economists, the connexion between growth and well-being is straightforward. In theory, an expanding economy typified by more market-based production cannot be attended with unemployment. That understanding earned Gerard Debreu a Nobel Prize in Economic Sciences in 1983, except that when journalists wanted to ask Professor Debreu questions about real-life conditions when he was visiting Australia, the great economist declined comment. Apparently, Debreu's economics could only be analysed within his rigorous mathematical models. ${ }^{2}$

That notable real-world challenge to orthodox economics happened in the 1980s, but continuing research and publications by social economists, including those in this Forum (Spiegler \& Milberg, 2013), demonstrate that the schism between the world of mainstream economists and the real world remains, arising not only from methodological deficits, but also from ontological and epistemological ones. The work of de La Grandville and Solow (2009) is one example where orthodox economists contend that the economic growth-wellbeing nexus is axiomatic. Henning (2013), Jerven (2013) and Kappel (2014) show that Africa's growth is unsustainable or that the statistical information is unreliable.

However, the logic of growth itself has gone unchallenged, except in a few cases (e.g. Fioramonti, 2013). Other commentaries on the systemic nature of the

1 For example, 'BBC Africa Debate: Africa Rising - Can The Middle Class Drive Growth?', $B B C$. Retrieved March 3, 2014, from http://www.bbc.co.uk/mediacentre/proginfo/2013/26/bbcafricadebate.html

2 This information comes from a discussion with an Australian social economist who was closer to this historic incident than the present author. 
challenges of the growth mantra have looked outside the African continent, however. Among them are three classics, namely Baran (1957), Mishan (1967) and Waring (1988). More recent analyses have appeared in this Forum, notably in the special issue on the political economy of development (Milonakis, 2012). While Africa-specific analyses are not captured in these accounts, doing so is crucially important because of the deployment of the growth measure to tell the story of Africa. So, in what follows, I examine the connexion between growth and jobs, distribution and ecology; growth narrative and the urban experience in Africa; and how else 'progress' can be measured-beyond growth.

\section{Jobs, Distribution, Poverty and Ecology}

Jobs, distribution, poverty reduction and ecological sustainability, all these are brought about by economic growth. Mainstream economists contend that all social problems can be resolved with increasing capital accumulation. With more growth, the poor will benefit and the jobless will find work, and the world will become more equal, cities more liveable and the environment more sustainable (Dollar \& Kraay, 2002). This 'growthmania', Mishan (1967, p. 3) famously observed, is 'like a national flag and a national airline, a national plan for economic growth is deemed an essential item in the paraphernalia of every new nation state'. For much mainstream economics work, Africa's growth record fully complies with the expectations of economic theory. There are strong connections and causations between economic growth and the rest: economic growth in Africa is powering precipitous declines in poverty levels on the continent, closing the income inequality gap, and will usher Africa into the promised land: achieving the Millennium Development Goals (Pinkovskiy \& Sala-i-Martin, 2014). To Young (2012), households in Africa are better off today because of economic growth. Increasing economic growth has powered tremendous achievements in education and quality housing, improved the ownership of assets and enhanced the quality of health in Africa. Although Africa remains poor, growth has produced a 'miraculous achievement' in transforming the continent (p. 732). So, policymakers will do well to continue in the path of more growth.

However, upon a closer scrutiny of the data used and the statistical techniques employed for this view, serious questions begin to emerge. Setting aside the generalising analyses that gloss over the different and differentiating characteristics of Africa as a continent, Harttgen, Klasen, and Vollmer (2013) and Rodrik (2014), among many others (e.g. Devarajan, 2013), have questioned the 'growth miracle' story, pointing to major deficits in the choice of comparable income data with some taken from national accounts and others compiled from 
international sources, inherent conceptual biases, and the deficiencies in the econometric models. So, while the work of Young (2012) and Pinkovskiy and Sala-i-Martin (2014) claim a 'growth miracle' and a perfect timing for Africa's growth and resulting ramifications, the overall effect of the challenges revealed by Harttgen et al. (2013) and Rodrik (2014) is that these studies do not provide accurate context-specific analysis of the African experience and, for Devarajan (2013), undermine national capacity to collect local and context-specific data. In fairness to some of these scholars (e.g. Young, 2012, pp. 699-700), however, they do acknowledge the many limitations in their approach and stress how their conclusion can be valid mainly on the basis of certain 'unreal' assumptions.

In real life, however, the situation is more complex. The relationship between growing economy and well-being is contingent. If growth is inclusive, ecologically sustainable and job creating, it offers stronger grounds to be optimistic. That is evidently what is happening in Mauritius and Botswana, as can be seen in Table 1. In both countries, growth has come with falling unemployment and poverty levels and, at least in the case of Mauritius, with declining income inequality. Decisive social interventions and programmes have been aggressively pursued in both countries. Like education, the cost of housing is low and the environment clean. Mark Twain once called Mauritius 'heaven'. In the last few years, it has been called 'paradise' (Highlife, 2014). The same sanguine picture cannot be painted of growing African economies such as Nigeria, South Africa and Zambia, to give only three examples. While these countries have experienced growth, levels of poverty continue to rise or, in the case of South Africa, remain nearly the same. Inequality has worsened in all these countries. What is even more disturbing in the South African case is that inequality is substantially worse than it was when the country was extricating itself from the shackles of apartheid in 1994.

Table 1: Current trends in Growth, Poverty, Inequality and Unemployment, ca. 2010-2014

Country Growth trend Poverty trend Inequality trend Unemployment trend

\begin{tabular}{lcccc}
\hline Mauritius & $\uparrow$ & $\downarrow$ & $\downarrow$ & $\downarrow$ \\
Botswana & $\uparrow$ & $\downarrow$ & $\uparrow$ & $\downarrow$ \\
Nigeria & $\uparrow$ & $\uparrow$ & $\uparrow$ & $\uparrow$ \\
South Africa & $\uparrow$ & $\leftrightarrow$ & $\uparrow$ & $\uparrow$ \\
Zambia & $\uparrow$ & $\uparrow$ & $\uparrow$ & $\uparrow$ \\
\hline
\end{tabular}

Sources: Distilled from Jean-Yves and Verdier-Chouchane (2010), Enweremadu (2013), Kent and Ikgopoleng (2011) and Chibuye (2014). 
Zambia has increasing levels of poverty, although it is among the fastest growing countries in Africa. In Nigeria, poverty levels have been rising, reaching some $61 \%$ in 2012, and economic growth has counted as neutral or positive the wide and vast ecological crises brought about by oil extraction. Violence has declined in the Niger Delta area and Shell Petroleum has ceased operations in Ogoniland, but the environmental crises have remained and worsened in some cases (Bassey, 2012; Okechukwu, Ukiwo, \& Ibaba, 2012).

The growth-based story of 'Africa on the rise' is problematic in spatial respects too.

\section{Spatial Mismatch}

The growth mantra says little or nothing about rural and urban life in Africa, although given the rate at which urban population is growing we need to understand the urban, spatial and regional aspects of growth and well-being. In a recent article on Economist Online published on 2 October 2012, and titled 'The urbanisation trap', The Economist observed that 'As a general rule, when people move to work in cities, it is synonymous with economic growth and the more people do the first, the more countries are offered the second'. Cities in Africa, it argued, do not live up to this expectation, so the urban population must be very unproductive or, put crudely, lazy.

This view about cities being production engines and the process of urbanisation being an effort to crank the engines of cities is faulty on many grounds. It misunderstands the nature of urbanisation and migration in Africa-a continent experiencing considerable urban-urban migration, secondary-primate city migration and even urban-rural migration. There is also region-region migration, international migration and cyclical migration on the continent. Much migration is temporary, although there is permanent migration within Africa too. Each of these dynamics has its peculiarities, although there are important similarities too, as recently shown by Ozkul and Obeng-Odoom (2013). Again, the growth mantra overlooks the institutionalisation of capitalist processes intended to keep certain regions underdeveloped, consigning and compelling indigenes of these regions to become a backward 'labour reserve' as we see in colonial and dependent urbanisation between Northern and Southern Ghana, demonstrated in Dickson's (1968) classic work and in more recent research (Songsore, 2011). So, to assume that cities arise because of only or mainly economic factors, one set (poverty and disease) pushing and another set (economic prosperity) pulling is conceptually problematic. Setting aside the faux claim about the lack of connexion between urbanisation and urban economic 
growth which exists in much of urban life in Africa (Njoh, 2003; Turok \& McGranahan, 2013)—something the World Bank (2009) has been forced to accept after much prevarication for ages-it is simplistic to assume that the urban population in Africa is unproductive.

The UN-HABITAT (2003) offered detailed information about high levels of productivity, creativity and innovation in various slums in Africa. More recent studies are consistent and further bring to light the activities of well-organised labour groups in slums in cities, such as Accra (Farouk \& Owusu, 2012) and Dar es Salaam (Hooper \& Ortolano, 2012), and other cities in Namibia (Muller \& Mbanga, 2012). Slums have extreme conditions too, of course, but that is the point: growth tells us little or nothing about the complexities and varieties of urban and rural life. In fact, as in these examples, growth emphasis can misinform. As an aggregate measure, the GDP does not show any spatial differences. While city authorities in Johannesburg, Durban and Cape Town compile urban-level GDP Figures (UN-HABITAT, 2010), growth can only tell us just that: growth. Questions of complexity, such as informal economies and how they operate, are overlooked, as the case studies highlighted in this paper illustrate.

There are other urban and regional dynamics that the 'Africa on the rise' story hides. Take the case of Ghana, for example. Obeng-Odoom (2014) shows that with oil, Ghana was growing around $14 \%$ but without oil the country had a growth rate of about $7 \%$ in 2011 . So, the economy was doing really well and the economic managers of the country consistently made this point. However, this story does not show important ethical problems of widening inequality between the oil city and other cities in Ghana, inequality between classes within the city, inequality between in-migrants and natives and inequality between genders-a very important concern because the current oil-generated jobs are concentrated in male-dominated sectors of the economy. Yet, by the dominant growth account, Ghana too is risingregardless of whether women in its oil city count for little or nothing.

Unfortunately, this growth-based view is what is influencing urban governance in Africa. In theory, urban governance is a broad-based process, drawing on a cluster of ideas from decentralisation, entrepreneurialism and democratisation. That is, governing cities not only by markets and the state but also by other actors (Obeng-Odoom, 2013). In practice, urban governance in Africa has come to represent a pro-market state working in cahoots with international real estate firms, property development consultants and global architectural firms. Together, these actors create 'urban fantasies', whole new cities or satellite cities with structures and form that mimic the architecture in Dubai and Shanghai. Such imported plans have little or no local-level input. They tend to supplant the public mandate of national planning authorities. In Rwanda, Kigali is expected to be replaced by a new city whose plans were accepted by the Rwandese Parliament in 
2008. Such plans exist in Addis Ababa, Accra and Nairobi. Their urban function is to inspire business confidence and to 'decongest' already crowded cities (Watson, 2013). It is not accurate, however, to regard actually existing urban governance as completely mutilating of local voices (Bhan, 2014). In urban Ghana, for instance, city residents have resorted to the use of the media especially phone-in programmes to hold the state to account (Selormey, 2013). Local and international civil society organisations such as Ghana Federation of the Urban Poor are actively involved in grass-roots organisation. Through the collection and presentation of data on people working in informal economies and settlements, politicians are beginning to be more careful in ordering evictions (Farouk \& Owusu, 2012). In South Africa, Community Organization Resource Centre in Cape Town works with the poor and have together developed a programme of enumeration to deter massive eviction, and it also tries to fight with the poor through the law courts. In Nigeria, Health of Mother Earth Foundation strongly criticises poor urban governance processes and outcomes. So, urban governance is market dominated but this market power is not going unchallenged.

Nevertheless, marketised urban governance has brought about many failings in urban development. While slum prevalence has declined by some $7 \%$ in North Africa and by $5 \%$ in sub-Saharan Africa, congestion in cities, increase in income poverty (UN-HABITAT, 2013) and worsening inequalities (UN-HABITAT, 2010) loom. Food security is a problem as is food sovereignty. Emissions from private secondhand cars are increasing as is the number of car accident-related deaths (World Health Organization, 2013), and urban waste (Selormey, 2013), be it electronic or plastic, is increasing.

Yet, not all is lost. Cities in Africa can contribute not just to Africa's development but also to a just African development. Inclusive and indigenised forms of planning constitute one way in which this can be done. Cities can unmake colonial planning policy of separating work from home. Spatial restructuring is possible and desirable to ensure less travel and less congestion and emission. Inclusive planning can be done with the media, civil society groups and above all residents in slums and informal settlements. As Africa now has urban corridors and city regions such as the Lagos-Ibadan-Accra corridor (UN-HABITAT, 2012), regionalisation can be more easily pursued to ensure better learning from one another, better collective strategising and better urban ecological approaches. The clustering of large sector of people can also make the state show its visible hand through the creation of urban transportation (Njoh, 2009). Indeed, the hand of the state can be reoriented to support small-scale urban agriculture, contrary to what is currently happening in Bameda in Cameroon (Ojong, 2011). There is considerable evidence that agriculture survives in urban and peri-urban environment and continues to be done in Africa (Lynch, Maconachie, Binns, Tengbe, \& Bangura, 
2012), so there is experience of how this can be done. Moving from 'here' to 'there' will not happen overnight, but it must eventually do so.

\section{Beyond Growth}

As a political-economic concept, 'beyond growth' can sound ambiguous, but on careful examination it is a concrete vision and approach to social and ecological economic analysis. Generations of social and ecological economists have devoted much time to its study theoretically and empirically. It is a 'limit to growth' thesis and goes way back to Mishan (1967) and Meadows, Meadows, Randers, \& Bahrens (1972). The Meadows Report strongly advocated stabilisation, even a reduction of growth, including the highly controversial recommendation of population control, and the cherished democratic ethos of allowing the nation state and its peoples to determine for themselves 'what is produced, how it is produced, and for whom it is produced'. 'Beyond Growth' provides a radical challenge to the mainstream advocacy of bigger and more integrated markets in the name of 'globalisation'. One 'beyond growth' advocate was Schumacher (1973) who upheld 'Budhist living', that is minimal consumption as an example of a beyond growth philosophy. Another beyond growth advocate is Daly (1990) whose notion of 'steady-state economics' is now widely used.

Like Schumacher's 'Budhist living', steady-state economics is not an Africanspecific argument, but a universal approach. It is based on the view that the ecosystem within which is the economy has a limit even if the solar system is regarded as limitless. According to Daly (2007), as the ecosystem cannot grow beyond its boundaries, it follows that the economic subsystem has constraints too. Beyond these limits, anymore economic growth is uneconomic in the sense that it hurts society to grow. While the hierarchies of limits do not work as a brickwall against which a car will typically crash, but rather like a budget against which one can borrow but at devastating consequences, the limits to growth are real and dire. The clash in the current capitalist world, Daly notes, is one between two impossibilities: one physical (ever-growing economic growth), the other political (the political challenge to stop economic growth). As the economy is cast within a finite biosphere and growth everlasting will eventually become 'uneconomic', the current model is likely to lead to clashes between human activities and natural abilities.

'Beyond growth', then, implies reversing the emphasis on growth in economic policy by destressing accumulation and realising its physical and ecological limits and Africa can play a part in this process. 
One way to commence this trans-growth and transformative journey is to deemphasise GDP stories and emphasise broader measures of well-being such as happiness. Gross national happiness as a policy priority is widely associated with Bhutan where since 1972 the economic managers of the country have focused their efforts at enhancing the happiness of the people of Bhutan-not their material goals. Even prior to 1972 and dating as far back as 1729, the country had a legal code obligating the leaders to make Bhutanese happy. Since the institutionalisation of constitutional monarchy in 2008, it is a constitutional duty (Article 9) for every leader of Bhutan to expand the frontiers of happiness in the country. Bhutanese stress spirituality in their conception of happiness, and humility and service are also emphasised as are sustainability and the concern for material suffering. These ingredients are systematically collected and analysed by the Centre for Bhutan Studies. The results of happiness analysis serve as the basis of policy in that country (Ura, Alkire, Zangmo, \& Wangdi, 2012). The Bhutan experience shows, then, that happiness is not just about emotions: it is much broader.

Generally, the ideas behind happiness go beyond money to wider considerations of love, cooperation, sharing quality time with friends and family, having a can-do attitude, good health, empowering education, spirituality and harmonious relationship with nature, sometimes to the point of worship. These can be measured, but not in the way orthodox economists propose to do it which is reductionist and narrow. For instance, Becker observed that 'love and other emotional attachments, such as sexual activity or frequent close contact with a particular person, can be considered particular nonmarketable household commodities' (1974, p. 327). This neoclassical economics view of the family is in sharp contrast with Keynes' deep insights on happiness in which he tries to capture 'the non-material, the non-optimal, the non(ir)-rational ... even the ephemeral and sometimes controversially referring to capitalism as a "spirit". But, it is symptomatic of neoclassical economics approaches to happiness which, as with other themes in orthodox economics, is narrow, often making little or no use of historical insights and social economics ideas (Carabelli \& Cedrini, 2011, p. 337). Psychologists and heterodox happiness economists typically use broader subjective measures such as employing the questions in the Oxford Happiness Inventory. There have been wide endorsements of the existing methodologies across different countries in the world and continuing attempts to improve how this broader measurement can be utilised, and the UN already collects subjective data on happiness (Argyle \& Lu, 1990; Schubert, 2012). In one such survey, income-poor countries such as Liberia and Sierra Leone were rated much higher in terms of 'living purposeful lives' than the UK and the USA, both of which are income-rich countries. 
Also, Table 2 reveals that the negative experience index (column 4) - the 'scale indicating the percentage of survey respondents in a Gallup World Poll who experienced a negative emotion such as physical pain, worry, sadness, stress, depression and anger the day before the survey' (UNDP, 2010, p. 224) demonstrates there are similar levels of emotional problems among African people as others in other regions (e.g. the USA and Australia). Furthermore, the

Table 2: The Ranking of a Selected Number of African Countries on Living a Purposeful Life, 2006-2009

\begin{tabular}{|c|c|c|c|}
\hline $\begin{array}{l}\text { Ranking on the basis } \\
\text { of population living a } \\
\text { purposeful life }\end{array}$ & Country & $\begin{array}{l}\text { People who agreed } \\
\text { that they have a } \\
\text { purposeful life }(\%)\end{array}$ & $\begin{array}{c}\text { Negative experience } \\
\text { index }(0, \text { most negative; } \\
100 \text { least negative })\end{array}$ \\
\hline 1 & Liberia & 100 & 27 \\
\hline 3 & Togo & 99 & 21 \\
\hline 3 & Malawi & 99 & 14 \\
\hline 3 & Mali & 99 & 13 \\
\hline 3 & Niger & 99 & 14 \\
\hline 3 & Namibia & 98 & 16 \\
\hline 3 & Kenya & 98 & 19 \\
\hline 3 & Ghana & 98 & 22 \\
\hline 3 & Cote d'Ivoire & 98 & 16 \\
\hline 3 & Sierra Leone & 98 & 37 \\
\hline 3 & Congo & 98 & 23 \\
\hline 20 & Sudan & 97 & 28 \\
\hline 28 & Benin & 96 & 24 \\
\hline 28 & Madagascar & 96 & 19 \\
\hline 28 & Uganda & 96 & 31 \\
\hline 28 & Guinea & 96 & 26 \\
\hline 28 & $\begin{array}{l}\text { Central African } \\
\text { Republic }\end{array}$ & 96 & 28 \\
\hline 49 & USA & 94 & 28 \\
\hline 90 & Australia & 87 & 22 \\
\hline 116 & UK & 79 & 24 \\
\hline
\end{tabular}

Source: UNDP (2010, pp. 176-179). 
countries with the smallest share of their populations reporting negative experience are all African countries, namely Mali (13\%), Niger (14\%) and Malawi (14\%). While a higher percentage of people in Sierra Leone (37\%) and Uganda (31\%) experienced negative experiences, the majority of the population are not distressed.

The other elements of happiness 'treated with respect' and 'social support network' in the UN data-sets, however, do not stand the African countries in good stead. Indeed, while the top 30 performers on social support are all outside Africa, the bottom 30 performers are mostly countries in Africa (18 out of 30). The two countries with the least social support were Togo and Benin where, respectively, only $28 \%$ and $38 \%$ of respondents answered 'yes' to the question about having social support. Also, while in all the African countries most people would answer 'yes' to being 'treated with respect', averagely, there are proportionately more people in other countries saying so than those in Africa. In turn, while the league of 30 best performers features only one African country-Niger where $93 \%$ of the population say they are treated with respect - the bottom 30 worst performing countries include six African countries-Madagascar (77\% yes), Rwanda (77\% yes), Tanzania (74\% yes), Ethiopia (74\% yes), Central African Republic (74\% yes) and Togo (54\% yes).

Other data in the UNDP tables on happiness (see UNDP, 2010, pp. 176-179) show that, while the other elements in the happiness measure are less flattering for the Africans, they confirm the bigger point: happiness is weakly linked with material progress. On the 'treatment with respect' element, more people (93\%) in Niger say they are treated with respect than several rich countries such as the UK (90\%), Australia (89\%) and Japan (60\%).

Similar trends - weak links between GDP and happiness - can be found in data collected by others. One such dataset can be found in the last World Happiness Report (Sustainable Development Solutions Network, 2013). The happiness data placed sub-Saharan Africa as the least happy region in the world. Also, the bottom five least happy countries in the world are all in Africa. On the other hand, richer countries in North America (the USA, Canada) and Australasia (Australia and New Zealand) rank in the happiest regions category. That said, nowhere in the world, not even in the richest countries, is the GDP the dominant contributor to happiness and it is certainly not the sole contributor to levels of happiness-social support, generosity and freedom to make life choices are also very important, if not more important. Indeed, if we exclude GDP from the calculations, sub-Saharan African countries have people showing much greater solidarity, as expressed in having people to count on, than in South Asia, the Middle East and North Africa. Furthermore, sub-Saharan African countries report higher levels of freedom in making life choices than in the Commonwealth of Independent States and in Middle 
East and North Africa. Again, people are more generous in sub-Saharan Africa, a materially poor region, than in Latin America and the Caribbean, Central and Eastern Europe. Finally, while the richest countries firmly occupy the league table of happiness, since 2005, there have been major declines in happiness levels, whereas countries in sub-Saharan Africa are typically becoming happier, and mostly because of non-income reasons such as freedom to make choices, levels of trust and solidarity (Sustainable Development Solutions Network, 2013, pp. 2-37).

What happens when we factor ecological concerns into happiness indicators? The last Happy Planet Index Report (New Economics Foundation, 2012) tried to address this pertinent issue. As with other measures of happiness, the Happy Planet Index uses well-being and life expectancy data. However, unlike other indices of happiness, the index uses the ecological footprint of countries too. Wellbeing is determined subjectively via interviews and hence it is called experienced well-being. The interview questions include the famous 'ladder of life' question which invites respondents to use a Likert scale of 0 (least happy life evaluation) to 10 (happiest life evaluation). Life expectancy data are taken from nationally reported hospital records (reported in the Human Development Reports) but they are adjusted so that it is the number of happy life years that is taken into account, while ecological footprint data are mostly gathered from the Global Footprint Networks. Mathematically, the index is simple to calculate for countries. For any country, first, determine the product of experienced well-being and life expectancy and then divide the result by the ecological footprint of that country. The result of this simple calculation is revealing: Algeria, a poor country in North Africa, ranks much better (26th) than many notable rich countries such as New Zealand (28th), the UK (41st) and Australia (76th). The materially rich countries make a poor showing in the list of 151 countries in which the USA is 105th, worse than Sudan (101st), Kenya (98th), Ethiopia (94th), Namibia (96th), Tunisia (39th) and Morocco (42nd). Indeed, even Denmark (110th), widely regarded as 'progressive', struggles on this index. To the writers of the report, if the world were to copy the excessive consumption in the USA in 2008, our world can no longer contain us: we will need four more planets to sustain us. So, a happy planet is not one with more accumulation or consumption. Indeed, $90 \%$ of the top 40 happiest countries by the HPI index have lower than or at most $\$ 15,000$ GDP per capita (New Economics Foundation, 2012).

Happiness research raises concerns exactly for these dramatic differences. One concern is that unscrupulous policy-makers thinking that their people are already happy may renege on their duty to provide public services on the pretext that citizens are already satisfied with their lives. This concern is an abuse of happiness research because people's levels of happiness can also be increased. In turn, what policy-makers should be doing is identifying the sources of happiness, target, 
support and try to enhance them, as they do in Bhutan. A second concern is not as straightforward. According to White (2013), there are a number of people who are happy to be sad or, put in other words, do not want to be happy.

What conclusion can be drawn from this important concern? One is to argue that, for such people at least, happiness cannot be a good measure of well-being. A second is more orthodox economics related. It is steeped in the ideas of benefitcost analysis in which the decision rule is to accept if the benefits exceed the cost. From this angle, the case of the 'happy sad' should be regarded as 'noise' in the data or ignore such people as they are in the minority. Arguably, it is considering happiness as one (even if the main) of many social and economic indicators only that is consistent with the critique that growth-based stories of Africa on the rise are incomplete and misleading.

That critique should be widened to examine the ramifications of the discourse, not only what it ignores but also what it generates. A discourse that Africa is rising almost invariably goes with the discourse that Africa is ripe for investment, which invariably leads to plunder of the common wealth in Africa. Such 'investments' in resources held in common such as water and physical land have generated massive exploitation and expropriation among agrarian groups in Africa. Under the caption, 'large scale investment in land', the World Bank and others such as the German Development Bank anoint this approach as the only way for Africans to prosper. That is, the current land grabs in Africa across the board-in Ghana, Togo, Sierra Leone, Ethiopia, Madagascar, Uganda and Sudan, to name only seven-and about which much has been written can be understood in terms of this growth discourse. But, even worse than present dispossessions are the dire future ramifications and costs. The discourse of growth externalises environmental costs in the West to Africa and elsewhere in poorer countries and sends more damaging speculative investment behaviour to the continent. Previous activities undertaken by Africans mainly for their use and sentimental value are being swept into the orbit of money and growth. Highlife magazine had a cover story in its February 2014 issue on Lagos, drawing attention to how international fashion investors have to flock to the city to see what money Lagos can offer them. Apparently, Lagos is fourth to New York, London and Paris, in the commodified fashion world. Written largely to showcase what is 'good in Africa', the effect of such discourse, especially when it is secularised and monitised, is to extend the reaches of markets to areas where their influence had been hitherto limited. Seen from this angle, the entire 'Africa on the rise' discourse is not only to showcase Africa as also a 'good continent' but also to set it up for further accumulation, exploitation and expropriation. As a world strategy, it has the tendency to oversimplify life in Africa, to package Africa and display it as a commodity on the market. 


\section{CONCLUSION}

This article is a modest effort, limited in two important ways. First, it does not generate new data to enrich the debate. Also, while some issues such as development and environment, economic growth and distribution of wealth, and economic polarisation are common in the Global South, the analysis is limited to Africa, making the scale of the contribution narrow.

Yet, it offers a timely critical perspective on the 'Africa is on the rise' discourse which hides more than it reveals in the sense that it is silent on jobs, ethical matters of distribution and ecological problems pervasive on the continent. It says little or nothing about spatial matters, provides a misleading framework for the complexities in the vast informal economies in Africa and opens wide Africa's doors for external plunder under the guise of 'investment'. While a few commentators may wish simply to tell good stories about Africa to reverse the negative publicity of the continent, this effort can be and often is compromised. Good storytelling has been co-opted or conscripted into a narrative about Africa for sale. The GDP discourse is, therefore, an effective political tool to excite markets about Africa. It works well in urban and regional contexts to encourage and stimulate the interest of leadership in Africa to open up markets, adore market culture and adorn market apparel in the form of buildings that mark the land and cityscape of market societies.

Wide-ranging social programmes common in Mauritius and Botswana have much to teach and to offer. Unfortunately, the attention Africa is receiving is not because of the limited but notable success in combining moderated growth with redistribution and ecological justice, but only in terms of growth. Here, we see the selectivity and conceptual preference of a particular mode of thinking over the rest. Highlighting more damaging discourses which show that Africa currently receives, but shoving under the carpet the continent's telling market contradictions either implicitly or explicitly serves as an important ideological purpose. So, without de-emphasising growth and re-emphasising broader ideals and ideas of well-being such as happiness and other socio-economic and ecological measures, Africa will be pushed into a growth egress and its economies may be said to be doing really well, but not its peoples, their environment or their relationship with nature.

\section{ACKNOWLEDGEMENTS}

Thanks to the three referees and the editors (Profs. Wolfram Elsner and Brian Chiang Lin) of Forum for Social Economics for helpful feedback on various drafts. The usual disclaimer applies. 


\section{REFERENCES}

Argyle, M., \& Lu, L. (1990). The happiness of extraverts. Personality and Individual Differences, 11, 1011-1017.

Baran, P. A. (1957). The political economy of growth. London: Monthly Review.

Bassey, N. (2012). To cook a continent: Destructive extraction and the climate crisis in Africa. Cape Town: Pambazuka Press.

Becker, G. S. (1974). A theory of marriage. In T. W. Schultz (Ed.), Economics of the Family: Marriage, Children, and Human Capital (pp. 299-351). Chicago, IL: University of Chicago Press.

Bhan, G. (2014). The real lives of urban fantasies. Environment and Urbanization, 26, 232-235.

Carabelli, A., \& Cedrini, M. (2011). The economic problem of happiness: Keynes on happiness and economics. Forum for Social Economics, 40, 335-359.

Chibuye, N. (2014). Interrogating urban poverty lines-The case of Zambia. Environment and Urbanization. doi:10.1177/0956247813519047

Daly, H. E. (1990). Steady-state economics. Washington DC: Island Press.

Daly, H. E. (2007). Ecological economics and sustainable development: Selected essays of Herman Daly. Cheltenham: Edward Elgar.

De La Grandville, O., \& Solow, R. (2009). Economic growth: A unified approach. Cambridge: Cambridge University Press.

Devarajan, S. (2013, October). Africa's statistical tragedy. Review of Income and Wealth, Series, 59, s9-s15.

Dickson, K. B. (1968). Background to the problem of economic development in Northern Ghana. Annals of the Association of American Geographers, 58, 686-696.

Dollar, D., \& Kraay, A. (2002). Growth is good for the poor. Journal of Economic Growth, 7 , $195-225$.

Enweremadu, D. U. (2013). Nigeria as an emerging economy? Making sense of expectations. South African Journal of International Affairs, 20, 57-77.

Farouk, B. R., \& Owusu, M. (2012). 'If in doubt, count': The role of community-driven enumerations in blocking eviction in Old Fadama Accra. Environment and Urbanization, 24, $47-57$.

Fioramonti, L. (2013). Gross domestic problem: The politics behind the world's most powerful number. London: Zed Books.

Fioramonti, L. (2014, February). Africa rising? Think again. Perspectives, 1, 6-9.

Fosu, A. (2010). Africa's economic future: Learning from the past. CESifo Forum, 11, 62-71.

Harttgen, K., Klasen, S., \& Vollmer, S. (2013). An African growth miracle? Or: What do asset indices tell us about trends in economic performance? Review of Income and Wealth, 59, S37-S61.

Henning, M. (2013). Africa and the middle class(es). Africa Spectrum, 48, 111-120.

Highlife. (2014). Highlife. London: British Airways.

Hooper, M., \& Ortolano, L. (2012). Motivations for slum dweller social movement participation in urban Africa: A study of mobilization in Kurasini, Dar es Salaam, of mobilization in Kurasini, Dar es Salaam. Environment and Urbanization, 24, 99-114. 
Jean-Yves, D., \& Verdier-Chouchane, A. (2010). Analyzing pro-poor growth in Southern Africa: Lessons from Mauritius and South Africa (Working Papers Series No. 115). Tunisia: African Development Bank.

Jerven, M. (2013). Poor numbers: How we are misled by African Development statistics and what to do about it. New York: Cornell University Press.

Kappel, R. (2014). Neither hopeless nor rising. GIGA Focus, 1-8.

Kent, A., \& Ikgopoleng, H. (2011). City profile: Gaborone. Cities, 28, 478-494.

Lynch, K., Maconachie, R., Binns, T., Tengbe, P., \& Bangura, K. (2012). Meeting the urban challenge? Urban agriculture and food security in post-conflict Freetown, Sierra Leone. Applied Geography, 1-9. Retrieved from http://dx.doi.org/10.1016/j.apgeog.2012.06.007

Mckinsey Global Institute. (2010). Lions on the move: The progress and potentials of African economies. Washington DC: Author.

Meadows, D. H., Meadows, D. L., Randers, J., \& Bahrens, W. W. III. (1972). Limits to growth. Washington, DC: Potomac Associates.

Milonakis, D. (2012). Introduction by the Guest Editor of the special issue. Forum for Social Economics, 41, 4-5.

Mishan, E. J. (1967). The costs of economic growth. Middlesex: Penguin Books/Staples Press.

Muller, A., \& Mbanga, E. (2012). Participatory enumerations at the national level in Namibia: The Community Land Information Programme (CLIP). Environment and Urbanization, 24, 66-75.

New Economics Foundation. (2012). The Happy planet index: 2012 Report. London: Author.

Njoh, A. J. (2003). Urbanisation and development in sub-Saharan Africa. Cities, 20, 167-174.

Njoh, A. J. (2009). The development theory of transportation infrastructure examined in the context of Central and West Africa. Review of Black Political Economy, 36, 227-243.

Obeng-Odoom, F. (2013). A critique of Africa's so-called failed development trajectory. African Review of Economics and Finance, 4, 151-175.

Obeng-Odoom, F. (2014). Oiling the urban economy: Land, labour, capital, and the state. London: Routledge.

Ojong, N. (2011). Livelihood strategies in African cities: The case of residents in Bamenda, Cameroon. African Review of Economics and Finance, 3, 8-24.

Okechukwu, U., Ukiwo, U. O., \& Ibaba, I. S. (Eds.). (2012). Natural resources, conflict, and sustainable development: Lessons from the Niger Delta. London: Routledge.

Ozkul, D., \& Obeng-Odoom, F. (2013). Temporary migration in Africa: Views from the Global South. African Review of Economics and Finance, 5(1), 1-6.

Pinkovskiy, M., \& Sala-i-Martin, X. (2014). Africa is on time. Journal of Economic Growth, 19. doi:10.1007/s10887-014-9103-y

Rodrik, D. (2014). An African growth miracle? Richard H. Sabot Lecture, delivered at the Center for Global Development. Washington, DC, April 24.

Schubert, C. (2012). Pursuing happiness. KYKLOS, 65, 245-261.

Schumacher, E. F. (1973). Small is beautiful: Economics as if people mattered. London: Blond and Briggs.

Selormey, E. E. (2013). Citizen voice and bureaucratic responsiveness: FM radio phone-ins and the delivery of municipal and local government services in Accra Ghana. ( $\mathrm{PhD}$ dissertation). Sussex University.

Songsore, J. (2011). Regional development in Ghana: The theory and the reality. Accra: Woeli. 


\section{AFRICA: ON THE RISE, BUT TO WHERE?}

Spiegler, P. M., \& Milberg, W. (2013). Methodenstreit 2013? Historical perspective on the contemporary debate over how to reform economics. Forum for Social Economics, 42, $311-345$.

Sustainable Development Solutions Network. (2013). World poverty report. New York: The Earth Institute, Columbia University.

Turok, I., \& McGranahan, G. (2013). Urbanization and economic growth: The arguments and evidence for Africa and Asia. Environment and Urbanization, 25, 465-482.

Twineyo-Kamugisha, E. (2012). Why Africa fails: The case for growth before democracy. Cape Town: Tafelberg.

UNDP. (2010). Human development report 2010. New York: Palgrave Macmillan.

UN-HABITAT. (2003). The challenge of slums. London: Earthscan.

UN-HABITAT. (2010). The state of African cities. Nairobi: Author.

UN-HABITAT. (2012). The state of African cities. Nairobi: Author.

UN-HABITAT. (2013). Unleashing the economic potential of agglomeration in African cities. Nairobi: Author.

Ura, K., Alkire, S., Zangmo, T., \& Wangdi, K. (2012). An extensive analysis of GNH index. Bhutan: The Centre for Bhutan Studies.

Watson, V. (2013). African urban fantasies: Dreams or nightmares? Environment and Urbanization, 26(1), 1-17.

Waring, M. (1988). Counting for nothing: What men value and what women are worth. Wellington: Allen \& Unwin/Port Nicholson Press.

White, M. D. (2013). Can we-and should we-measure well-being? Review of Social Economy, $71,526-533$.

World Bank. (2009). World development report 2009: Reshaping economic geography. Washington, DC: Author.

World Health Organization. (2013). Global status report on road safety. Geneva: Author.

Young, A. (2012). The African growth miracle. Journal of Political Economy, 120, 696-739. 